Indian Joumal of Clinical Biochemistry, 2001, 16(2), 221-223

\title{
THYROID HORMONE STATUS IN PROTEIN ENERGY MALNUTRITION IN INDIAN CHILDREN
}

\author{
Pankaj Abrol*, Ashok Verma* and H. S. Hooda**
}

Departments of Pediatrics* and Radiotherapy** Pt. B.D. Sharma Post Graduate Institute of Medical Sciences, Rohtak-124001.

\begin{abstract}
Thyroid hormonal status was measured in $\mathbf{8 0}$ malnourished children of different grades (I-IV) of protein energy malnutrition (PEM). Serum lovels of tri-iodo thyronine $\left(T_{3}\right)$, thyroxine $\left(T_{4}\right)$ and thyroid stimulating hormone (TSH) were measured by radioimmunoassay. The results were compared with 20 healthy, age and sex matched controls. Levels of $T_{3}$ and $T_{4}$ were significantly low in PEM cases whereas TSH levels were similar in PEM cases when compared to controls.
\end{abstract}

KEY WORDS : Thyroid hormones, Protein energy malnutrition.

\section{INTRODUCTION}

Protein energy malnutrition (PEM), an important cause of childhood morbidity and mortality, leads to permanent impaiment of physical and possibly mental growth of those who survive. The problem is most widespread in south Asia, home to half of wortd's malnourished children. UNICEF reports that India has unfortunate distinction of having 75 million mainourished children below 5 years of age. In PEM as the supply of protein and energy is limited, the body tries to use them more economically by decreasing the besal caloric expenditure. A variety of endocrine abnormalities have been reported in PEM, like changes in growth hormone, insulin, glucocorticoids and thyroid hormones. The changes in thyroid homeostasis have not been given enough focus $(1,2)$. In PEM, there are marked changes in secretion and metabolism of thyroid hormones and in the structure of thyroid gland. This results in reduction of the activity of the gland (3), as the body tries to adapt to low calorie intake. Though few studies have been done on status of thyroid hormones, the studies on $\mathrm{T}_{3}$ levets in infarts and children are not many $(4,5)$.

Author for comespondence:

Dr. Pankaj Abrol, at above address,

Tel.: 01262-41353, E-mail : abrot06@encb.vsri.netin

\section{MATERIALS AND METHODS}

The study was carried on 80 malnourished children aged 1-4 years, comprising of 4 grades of PEM (I-IV), according to Indian Academy of Pediatrics classification (6). These were grouped A, B, C and D of $\mathbf{2 0}$ children of each grade. Twenty healthy children were taken to serve as controls (group E). All the groups were age and sex matched. Exclusion criteria included all infections including tuberculosis and urinary tract infection (UTI). None of these children had endocrine and metabolic disorders.

$T_{3}, T_{4}$ and $T S H$ were measured in all the children. RIAK-4/4A kit was used for quantitative estimation of $T_{3}$ by radioimmuno assay (RIA). $T_{4}$ was also measured quantitatively by RLA using RIAK-5/5A kit. IRMA-9 kit was used for an ultra sensitive solid phase-two site Immunoradiometric assay (IRMA) for human TSH.

Descriptive statistical analysis was done using unpaired ' $t$ ' test for comparing the mean in different groups. The co-efficient of correlation ( $r$ ) was calculated wherever required.

\section{RESULTS AND DISCUSSION}

In the present study mean age of PEM cases 
was $28.9+1.3$ months, whereas in controls it was 31.4+2.7 months. Seventy one percent of PEM cases and $75 \%$ in controls were males. These differences were not statistically significant. Because of prevalent sociological factors in the region the male children are given preference. Table 1 shows weight distribution in all the groups. In PEM cases mean weight was $7.9+0.2 \mathrm{Kg}$., and in controls it was $12.5+0.4 \mathrm{Kg}$. All PEM cases had low hemoglobin and serum albumin levels when compared to controls (not shown). The difference was statistically insignificant when different grades of PEM (Groups A-D) were compared to each other.

Table 1. Body weight, serum $T_{3}, T_{4}$ and $T S H$ in PEM and controls.

\begin{tabular}{|c|c|c|c|c|}
\hline $\begin{array}{l}\text { STUDY } \\
\text { GROUP }\end{array}$ & $\begin{array}{l}\text { Body } \\
\text { Wt. (kg.) }\end{array}$ & $\mathrm{T}_{3}(\mathrm{ng} / \mathrm{dl})$ & $T_{4}(\mu \mathrm{g} / \mathrm{dl}) \mathrm{TS}$ & $\mathrm{SH}(\mathrm{m} / \mathrm{U} / \mathrm{L})$ \\
\hline Gr. (PEM) & $10.1 \pm 0.4$ & 126.9 & $4 \pm 0.5^{*}$ & $2.4 \pm 0.2$ \\
\hline (Gr. \| PEM) & $8.6 \pm 0.3$ & 122. & $0 \pm 0.8^{\circ}$ & $4 \pm 0.4$ \\
\hline$C$ (Gr. III PEM) & $7.3 \pm 0.3$ & $106.5 \pm 9.8$ & $8.0 \pm 0.8^{m}$ & $2.9 \pm 0.4$ \\
\hline (Gr. IVPEM) & $6.1 \pm 0.2$ & $90.3 \pm$ & $7.7 \pm 0.5^{m}$ & $2.6 \pm 0.3$ \\
\hline $\begin{array}{l}\text { Mean of all } \\
\text { 'PEM' cases }\end{array}$ & $8.0 \pm 0.2^{n+1+}$ & $111.5 \pm 5.6^{\mathrm{m}}$ & $8.5 \pm 0.3^{m}$ & $2.6 \pm 0.2$ \\
\hline \multicolumn{2}{|c|}{$\begin{array}{l}=\text { Control } 12.5 \pm 0.4 \\
=\end{array}$} & $157.8 \pm$ & 10.55 & $246 \pm 0.24$ \\
\hline
\end{tabular}

Velues are mean $\pm S E M, n=20$ in each group

' $p<0.05: " p<0.01: \cdots " p<0.001$ when compered to controls.

Table 1. also shows thyroid hormones levels in children with different grades of PEM and in controls. It shows that $T_{3}$ levels were significantly low in groups $B-D$ (PEM grade II-IV). The hormone $T_{4}$ levels were significantly lowin all the groups (A-D) of malnourished children. The levels of TSH however, were similar in all the groups of PEM cases when compared to controls $(p>0.05)$.
Correlation co-fficient was calculated for $T_{3}, T_{4}$ and TSH against weight for age in PEM cases and controls. All values were statistically insignificant ( $p>0.05$ ). Value of ' $r$ ' was 0.212 for $T_{3}, 0.197$ for $T_{4}$ and -0.129 for TSH.

In the present study, $T_{3}$ levels were found to be, significantly decreased in PEM cases. Studies from Bangladesh (7) and Turkey (8) also reported that the mean total $T_{3}$ and $T_{4}$ levels were significantly lower in PEM cases as compared to controls. Animal studies have shown that during starvation, $T_{4}$ uptake by liver (9) and the activity of enzyme 5-deiodinase (10) are decreased.

Low levels of thyroid hormones binding proteins in malnutrition are thought to be due to decreased protein intake and their reduced hepatic biosynthesis (11). The rise in serum total $T_{3}$ and $T_{4}$ levels that occur on re-feeding can be largely accounted for by the increasing concentration of TBG, TBPA and albumin. By contrast, children who do not receive adequate nutritional supplements do not show significant changes in levels of these proteins $(1,4,12)$. After thyroid hormones binding proteins decrease, free thyroxine levels also fall and that explains altered thyroid functions in PEM (13). Low serum $\mathrm{T}_{3}$ level is probably an adaptive change in malnutition to conserve body proteins. As in earlier studies $(4,14)$, in present study also, there was insignificant difference between TSH levels in PEM cases and controls.

Changes in thyroid metabolism in PEM probably represent adaptive changes to the diseased state of malnutrition. So treatment with L-thyroxine to restore serum thyroid hormones to the normal range per se is not indicated.

\section{REFERENCES}

1. Ingenbleek, Y. (1986) Thyroid dysfunction in protein calorie malnutrition. Nutr. Rev. 44, 253-262.

2. Wartofsky, L. and Burman, K. (1982) Alterations in thyroid function in patients with systemic illness. Endocr. Rev. 3, 164-217.

3. Stirling, G.A. (1962) The thyroid status in malnutrition. Arch Dis Child 37, 99-102. 
4. Hatemi, N., Haktan, M., Genca, E. and Cuma, T. (1982) Thyroid function in protein energy Malnutrition. Turk. J. Pediatr. 24, $29-34$.

5. Turkay, S., Kus, S., Gokalp, A., Baskin, E. and Onal, A. (1995) Effects of protein energy malnutrition on circulating thyroid hormones. Ind. Pediatr. 32, 193-197.

6. Nutrition sub-committee of Indian Academy of Pediatrics report. (1972) Ind. Pediatr. 9, 360-363.

7. Khatun, F.U.H., Khan, M.R., Ara, F., Ahmad, K. and Choudhury, S.A. (1982) Study of thyroid functions in protein energy malnutrition. Bangladesh Med. Res. Counc. Bull. 8, 68-71.

8. Orbak, Z., Akin, Y., Varoglu, E. and Tan, H. (1998) Serum thyroid hormone and thyroid gland weight measurements in protein energy malnutrition. J. Pediatr. Endocrinol. Metab. 11, 719-724.

9. Jenning, A.S., Ferguson, D.C. and Utiger, R.D. (1979) Regulation of the conversion of thyroxin to tri-iodothyronine in the perfused rat liver. J. Clin. Invest. 64, 1614-1619.

10. Balsam, A. and Ingbar, S.H. (1978) The influence of fasting, diabetes and several pharmacological agents on the pathways of thyroxin metabolism in rat liver. J. Clin. Invest. 62, 415-423.

11. Kalk, W.J., Hofman, K.J., Smit, A.M., Drimmelen, M.Y., Walt, L.A. and Moore, R.E. (1986) Thyroid hormone and carrier protein interrelationships in children recovering from kwashiorkor. Amer. J. Clin. Nutr. 43, 406-413.

12. Ingbar, S.H. (1985) The thyroid gland. In: William's Textbook of Endocrinology. Eds. Wilson JD, Foster DW $7^{\text {th }}$ edn. W.B. Saunders, Philadelphia, USA p.726-727

13. Tibaldi, J.M. and Surks, M.I. (1985) Effects of non-thyroidal illness on thyroid function. Med. Clin. North. Am. 69, 899-911.

14. Schalch, D.S. and Cree, T.C. (1985) Protein utilisation in growth: Effect of calorie deficiency on serum $\mathrm{GH}$, somatomedins, total $\mathrm{T}_{4}$, total $\mathrm{T}_{3}$, free $\mathrm{T}_{4}$, index and total corticosterone. Endocrind. 117, 2307-2312. 